\title{
Osama D. Sweidan* Political Instability and Economic Growth: Evidence from Jordan
}

DOI 10.1515/rmeef-2015-0025

Published online November 30, 2016

Abstract: This paper explores the link between political instability and economic growth in Jordan, which is a lower middle-income country located at the heart of the Middle East. Historically, this region has been living under protracted wars, clashes, violence and terrorist attacks. We can expect these events to influence economic growth via their effect on government spending. We employ two econometric techniques: ARDL model (OLS) and Kalman filter (ML) and use data over the period 1967-2009. We find political instability has a statistically significant negative effect on economic growth as well as on real government expenditures.

Keywords: political instability, growth rate of real income per capita, real government spending, Jordan, ordinary least squares, Kalman filter

JEL Classification: C13, 040, 043

\section{Introduction}

The linkage between political instability and economic growth has been attracting the attention of economists over the last four decades. Several empirical results have showed that political instability harms economic growth (Jong-APin 2009; Alesina et al. 1996). Also, political instability condenses physical capital (Aisen and Veiga 2013) and may lead to a drop in investment (Alesina and Perotti 1996; Barro 1991; Rodrik 1989; Schneider and Frey 1985). Furthermore, some economists have indicated that political instability often cuts foreign direct investment (Alfaro et al. 2008; Busse and Hefeker 2007; Daude and Stein 2007) may cause high inflation rates (Aisen and Veiga 2006; Cukierman, Edwards, and Tabellini 1992). Recently, the United Nations (2015) declared that political instability is an important country-specific weakness and has been disrupting production in many developing countries.

*Corresponding author: Osama D. Sweidan, College of Business and Economics, Department of Economics and Finance, United Arab Emirates University, P.O. Box 15551, Al-Ain, UAE,

E-mail: osweidan@uaeu.ac.ae 
Most empirical studies concerning the economics of political instability rely on extracting evidence from panel data drawn from several countries (for instance, see Alesina et al. 1996; Aisen and Veiga 2013). By contrast, the present paper seeks to extract evidence about the affect of political instability on economic growth from a single country, Jordan. Why Jordan? First, Jordan has not yet had the benefits from an empirical understanding of the quantitative influence of political instability on the rate of growth of its real income per capita. Second, Jordanians live at the heart of the Middle East (ME), which is presently the hottest area in the world and full of political events, continuous clashes, wars and, lately, terrorist attacks. Worman and Gray (2012) reported around 80 incidents of terrorism and political violence in Jordan between 1970 and 2010. Choucair (2006) reported on political instability events in Jordan from its independence in 1947 to 2006. She stated that, since Jordan's establishment, the Hashemite Monarchy has faced real threats as a political institution. Consequently, it has been restricting political rights and freedom in Jordan. Recently, Zeaiter, El-Khalil, and Fakih (2015) found that strengthening political rights, civil liberties, and fighting corruption are important for promoting economic development. Since the late 2010s, the Middle East and the North African (MENA) region have gone through several events that, in turn, posed real threats to the stability of the regime in Jordan. The Islamist movements in the MENA countries have given Jordan's Islamists a push toward transforming Jordan into an Islamic state. As a result, massive protests had broken out in Amman, Zarqa, and Irbid. The resulting clashes with Jordanian security forces were difficult to be suppressed without a large number of lives being lost and without attracting foreign fighters from Syria, Egypt, and Iraq. All this put the regime's survival in serious jeopardy. ${ }^{1}$

Many external political events have also been affecting Jordan continually. It is believed that these external political events have also been creating internal political instability. For example, Jordan has had the largest number of cabinet reshuffles in the world; it has changed its cabinet nearly 41 times during the period 1967-2009, ${ }^{2}$ with each Jordanian government surviving for no more than one year. All these observations prompt the following question: Has political instability, be it internal or external, been influencing Jordan's economy? Also, have political events been influencing real government spending in Jordan? We contribute to this topic by using two econometric techniques: ordinary least squares (OLS) method and Kalman filter, i. e., the Maximum Likelihood method

1 Source Robert Satloff and David Schenker: http://www.cfr.org/jordan/political-instabilityjordan/p30698.

2 Source: http://www.pm.gov.jo/arabic/index.php?page_type=govdb3\&part=1. 
(ML) to estimate the coefficients of our model. Next, we compare the findings from the two methods. We organize the rest of the paper as follows. Section 2 discusses certain major facts about economic performance and political instability in Jordan. Section 3 reviews relevant literature. Section 4 presents the data analyzed. Section 5 describes the methodology and the model. Section 6 summarizes the empirical results. Based on the results, Section 7 examines the relationship between political instability and real government expenditure. We draw our conclusions in the final section.

\section{Economic Performance and Political Instability in Jordan: Some Facts}

Jordan is a small open economy with about 6.4 million inhabitants and an annual per capita income at current market prices equal to $\$ 4839.3$ (in 2012). The value of real gross domestic product (RGDP) in 1994 prices was $\$ 14.8$ billion in 2012. In 2012, the Jordanian economy registered a real growth rate of $2.7 \%$ compared to $2.6 \%$ in $2011 .^{3}$ This means that real per capita income grew by only $0.4 \%$ between 2011 and 2012. The inflation rate reached 4.7\% in 2012 and unemployment rate was $15.7 \%$ in 2013.

Jordan's economy has generally favored the services sector. In 2012, the service sector accounted for $66.2 \%$ of GDP, the rest was accounted for by Jordan's commodity production sector.

The Jordanian economy has been volatile and experiencing economic shocks resulting from higher international oil prices and higher food prices. At the same time, it has been at the core of the political developments in the Middle East, which has meant that, historically, all the intense political instability (internal as well as external) - clashes, wars, violence, and their consequences - witnessed in the region have directly affected Jordan's economy. For instance, Jordan had to host a large number of immigrants for short as well as long periods of time, which created huge pressures on its limited resources and weak production base (Sweidan 2013). A World Bank report in 2004 stated clearly that Jordan in the 1990s has not been able to meet the expectations in economic growth because of regional political uncertainty. ${ }^{4}$

3 The base year is 1994.

4 I will refer to this report when needed in my paper under the citation of Ramachandran (2004). 
Jordan relies heavily on external aid and external loans to realize its economic development plans. ${ }^{5}$ The country received around JD 11.9 billion as total external aid over the period of 1967-2011. The outstanding balance of external public debt reached JD 4.9 billion by the end of 2012. This financial support was received mainly from several industrial countries, Arab countries, foreign banks (e. g., Islamic Development Bank), and the international financial institutions like the International Monetary Fund (IMF) and the World Bank (WB). ${ }^{6}$ Sharp (2014) wrote "The United States has provided economic and military aid, respectively, to Jordan since 1951 and 1957. Total U.S. aid to Jordan through FY2013 amounted to around $\$ 13.83$ billion. Levels of aid have fluctuated, increasing in response to threats faced by Jordan and decreasing during periods featuring political differences or declines of aid worldwide". This statement is interesting because foreign aid and loans to Jordan have been fluctuating and are related to the political interest of the donors. In the same vein, Harrigan, Chengang, and El-Said (2006) showed qualitatively and quantitatively that donor interest, including geopolitical interest, influences who gets aid and how much. Donor interest plays a greater role with respect to bilateral aid grants than multilateral aid distribution. Their analysis focused on five MENA countries: Algeria, Jordan, Morocco, Tunisia, and Egypt. They found little evidence that donors connected their loans to significant deterioration in the macroeconomic indicators. By contrast, they attributed geopolitical reasons to these loans, e. g., a pro-western foreign policy, peace overtures to Israel, domestic political liberalization, and the often related challenge to the regime by Islamic opposition. ${ }^{7}$ Moreover, Ramachandran (2004) identified some determinants of the government spending in Jordan. These points are summarized below.

First, the report analyzed mainly the effect of the declines in oil prices during the late 1980s and the 1991 Gulf War on the Jordanian economy. The report stated that those two events devastated the finances of Jordan. Second, although government expenditures had risen in the 1970s when generous neighbors shared their oil wealth through grants, the Jordanian government had to reduce capital but not current spending when the sizes of these grants declined. This important finding links the relationship between a reduction in government spending and economic growth in Jordan. Third, foreign grants

\footnotetext{
5 Choucair (2006) mentioned that seeking aid has been a strategy since the establishment of Jordan. The initial donor was Britain. Afterwards, the monarch was able to convince the US and conservative Arab states of its important role in maintaining regional security.

6 Central Bank of Jordan, Yearly Statistical Series at: http://www.cbj.gov.jo/pages.php.

7 For more readings relating to the same idea see Harrigan and Wang (2004), Rodrik (1995), and Maizels and Nissanke (1984).
} 
have been declining since 1980. Fourth, the report explicitly recommended assistance to support a significant reduction in government expenditure.

It is clear from the above observations that political instability in Jordan has been gravely affecting external aid and loans to the country and, in turn, influencing government expenditures and economic growth. This is the rationale behind the present paper's objective to examine the effect of political instability on the growth rate of real income per capita. We conjecture that the government expenditure is a transmission channel between political instability and economic growth in Jordan.

We now present and adopt two definitions of political instability for GyinmahBrempong and Traynor (1999) and Burger, Ianchovichina, and Rijkers (2013). The first introduces political instability as "these events generate uncertainties about the stability of the present political system and/or government, and this uncertainty negatively impacts the authority and effectiveness of government” (p.54). Similarly, Burger, Ianchovichina, and Rijkers (2013) define political instability as "the propensity of a country to experience regime or government change; political, religious, and ethnic violence; as well as practices that have a detrimental effect on contracts, law and order, and the stability and efficiency of institutions" (p. 4). Based on these definitions, we can conceptualize political instability in terms of four ideas: cabinet changes in Jordan, local wars and violence, wars and violence in neighboring states, and wars and violence in regional states. Table 1 presents the main

Table 1: Local, borders, and regional political instability events related to Jordan.

\begin{tabular}{lll}
\hline No. & Political event & Period \\
\hline 1. & Cabinet changes, around 80 times & $1967-2013$ \\
2. & Six-day War & 1967 \\
3. & Karamah War & 1968 \\
4. & Tension and clashes between Jordanian troops and Palestinian groups & $1968-1970$ \\
5- & October War & $1973-1974$ \\
6. & Lebanon Civil War & $1975-1990$ \\
7. & Invasion of Lebanon & $1982-1983$ \\
8. & First Gulf War (Iraq-Iran War) & $1980-1988$ \\
9. & Second Gulf War (Invasion of Kuwait) & $1990-1991$ \\
10. Invasion of Iraq & $2003-2011$ \\
11. July War in Lebanon (with Israel) & July-August 2006 \\
12. War on Gaza & 2008 \\
13. Crisis in Syria & $2011-$ till now \\
14. Political Instability in Egypt & $2011-$ till now \\
\hline
\end{tabular}

Source: Jordan's Prime Ministry web site and different sites on the Internet. 
local, border, and regional political instability events related to Jordan. The table shows that Jordan lived in conditions of noticeable political instability and turbulence over the period 1967-2009.

\section{Literature Review}

Economists generally agree that there is a close relationship between political instability and economic growth. Gupta (1990) described this as follows: "without political stability the people cannot have confidence in their economy, and when faith is lacking, the people find safer places to place their monies, rather than in the economy". However, empirical support to these contentions has been in short supply. There have also been questions about the definitions of political instability and the corresponding measurements, selection of explanatory variables, insufficient sensitivity analysis, and failure to examine causality. Jong-APin (2009) examined the multidimensionality of political instability using 25 political instability signals in his Exploratory Factor Analysis. He found that political instability has four dimensions: instability within the political regime, mass civil protest, politically motivated violence, and instability of the political regime. Next, he tested the influence of political instability on economic growth using a dynamic panel system (Generalized Method of Moments model). He concluded that four dimensions of political instability impact economic growth differently while only political regime instability has a robust and significant negative effect on economic growth.

Literature shows that economists have generally tested the empirical link between political instability and economic growth at three levels. First, political instability affects economic growth (Aisen and Veiga 2013; Campos and Nugent 2002; Alesina et al. 1996; Olson 1991). Second, economic growth is a major cause of political stability (Zablotsky 1996). Third, the relationship between political instability and economic growth is bidirectional (Gyinmah-Brempong and Traynor 1999; Kirmanoglu 2003). In theory, Alesina et al. 1996) had argued that an unstable political environment produces uncertainty which negatively impacts private investment, physical capital accumulation and, therefore, economic growth. On the other hand, weak economic performance can lead to a collapse of the government and, hence, political instability. Campos and Nugent (2002) stated that economic growth leads to either higher or lower political instability. The former occurs because growth could motivate structural changes that undo political alliances and bring painful readjustments in the balance of power among different interest groups. The latter occurs because it moderates 
social and political tensions. ${ }^{8}$ Empirically, the investigation of the influence of political instability on economic growth uses either cross-sectional ${ }^{9}$ or regionspecific estimations. ${ }^{10}$

\section{Data}

We gathered yearly data on economic variables and political instability indicators of the Jordanian economy over the period 1967-2009. All the variables are transformed by using the natural logarithm form. Table 2 presents the summary statistics of those variables, which are used in our study. We adopt the rule of thumb proposed by Hahs-Vaughn and Lomax (2013), which recommends that the healthy range for skewness (SK) as well as kurtosis (KUR) is \pm 3 of the standard error for each. The standard error for $\mathrm{SK}=\sqrt{\frac{6}{43}}=0.373544$ and the standard error for $\mathrm{KUR}=\sqrt{\frac{24}{43}}=0.747087$. The acceptable ranges are $+1.1206-0.1 .1206$ and $+2.2412-2.2412$, respectively. The variables for skewness distributions are within the acceptable range. However, the kurtosis distributions are outside the acceptable range for the last three variables. Meanwhile, we cannot reject the null hypothesis of

Table 2: Summary statistics of the economic variables.

\begin{tabular}{lrrrrrr}
\hline & LnY $_{\boldsymbol{t}}$ & $\boldsymbol{L n M}_{\boldsymbol{t}}$ & $\boldsymbol{L n P}_{\boldsymbol{t}}$ & LnI $_{\boldsymbol{t}}$ & $\boldsymbol{L n G}_{\boldsymbol{t}}$ & $\boldsymbol{L n R}_{\boldsymbol{t}}$ \\
\hline Mean & 7.038 & 7.443 & 3.693 & 6.821 & 6.785 & 7.136 \\
Med. & 7.013 & 7.881 & 3.704 & 6.852 & 6.983 & 7.310 \\
Max. & 7.409 & 9.555 & 4.782 & 7.925 & 7.923 & 8.014 \\
Min. & 6.687 & 4.543 & 2.163 & 6.024 & 5.073 & 5.996 \\
S.D. & 0.196 & 1.533 & 0.816 & 0.461 & 0.719 & 0.569 \\
Skew. & -0.112 & -0.592 & -0.511 & 0.110 & -0.710 & -0.640 \\
Kur. & 2.221 & 2.017 & 1.966 & 2.702 & 2.723 & 2.351 \\
JB & 1.178 & 4.241 & 3.793 & 0.245 & 3.754 & 3.695 \\
Prob. & 0.555 & 0.120 & 0.150 & 0.885 & 0.153 & 0.158 \\
Obs. & 43 & 43 & 43 & 43 & 43 & 43 \\
\hline
\end{tabular}

8 For more theoretical readings regarding why political instability slows down economic growth and reduces investment see Collier (1999), De Haan and Siermann (1996), and Alesina et al. (1996).

9 For example see Aisen and Veiga (2006), and De Haan and Siermann (1996).

10 For example see Zureiqat (2005), Campos and Nugent (2002), and Campos, Nugent, and Robinson (1999). 
normal distribution for all the economic variables because the arque-Bera (JB) test leads to a conclusion of statistical insignificance. Data have shown that, because it has the highest standard deviation, money supply is the most volatile variable among the six economic variables. The sources for these economic data are the central bank of Jordan and the Econstat website, and the source of the political instability proxies is the Integrated Network for Societal Conflict Research (INSCR). ${ }^{11}$

We also had to examine how we could arrive at reliable results notwithstanding the fact that only limited data are available on the Jordanian economy.

Data relating to political instability have four dimensions: cabinet changes ${ }^{12}$ in Jordan, local wars and violence, wars and violence in neighboring states, and wars and violence in regional states. ${ }^{13}$ This implies that we have four different proxies of political instability. Next, we extracted a fifth political instability proxy from the four proxies by using the exploratory factor analysis. This technique is a data reduction method and can be used to create indexes with variables that measure similar things. Also, it extracts only the information common to all indicators (Wansbeek and Meijer 2000). Table 3 summarizes the data used in the principle factor analysis. Factor loading illustrates the weights between the variables and the loading factor and the correlation between each pair of variables. For example, in Table 3 the loading factor affects cabinet changes by 0.70 and local instability by 0.49 . As a result, the correlation between cabinet changes and local instability is 0.34 . Communality refers to the percentage variance of each variable shared with other variables. ${ }^{14}$ Uniqueness is the percentage of the variance that is unique to the variable and not shared with other variables. The summation of uniqueness and communality equal to

Table 3: Data summary of principle factor analysis.

\begin{tabular}{lrrr}
\hline The variable & Loadings factor & Communality & Uniqueness \\
\hline Cabinet changes & 0.70 & 0.49 & 0.51 \\
Local instability & 0.49 & 0.24 & 0.76 \\
Border instability & 0.96 & 0.91 & 0.09 \\
Regional instability & 0.94 & 0.88 & 0.12 \\
\hline
\end{tabular}

11 The website of the Network is: http://www.systemicpeace.org/inscrdata.html.

12 The source of cabinet changes in Jordan is the Prime Ministry website: http://www.pm.gov. jo/arabic/index.php?page_type=govdb3\&part=1.

13 For more details, see Appendix A.

14 The sum of the squares of the loadings for each variable. 


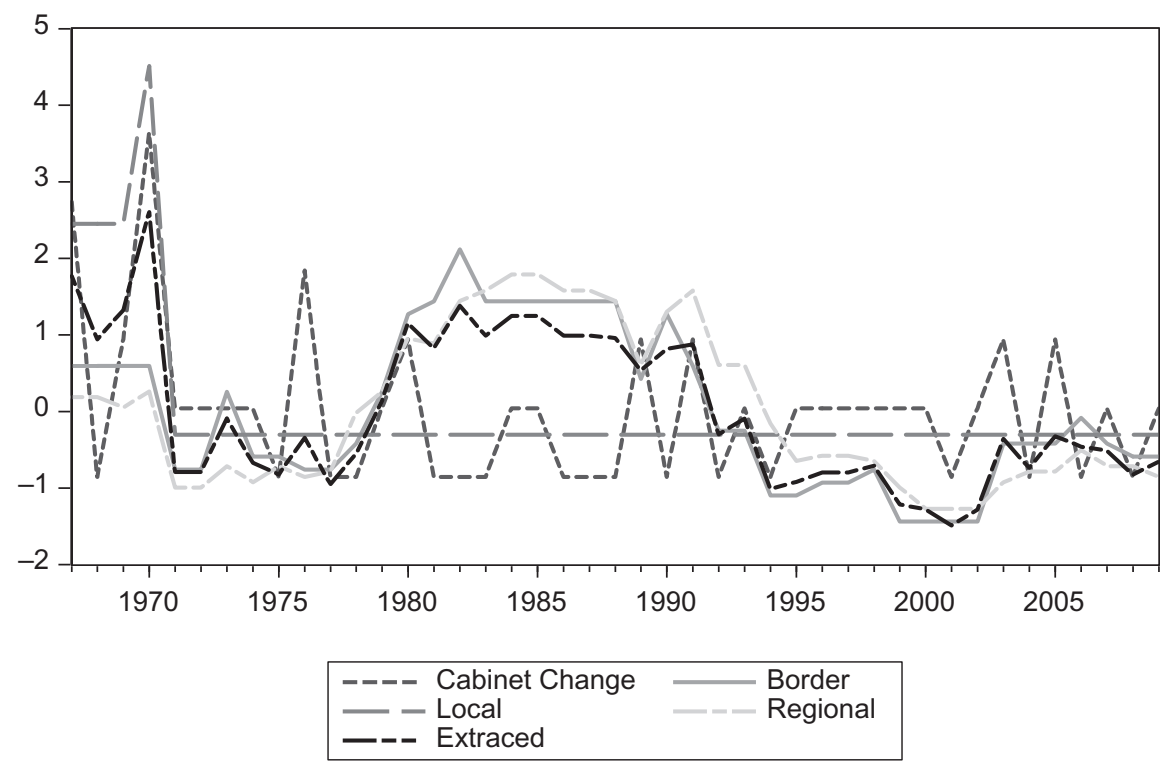

Figure 1: The five political instability indicators.

one. For example, in Table 3 around 0.49 of the variation of cabinet changes shared with the other variables, and the rest, 0.51 of cabinet changes is not shared with the other variables in the overall factor model. Figure 1 presents the five political instability indicators in Jordan. ${ }^{15}$

\section{Methodology and Model}

We employed two econometric techniques to compare and guarantee robust results and conclusions. These two techniques are: First, ordinary least squares (OLS): we use this method to examine the effect of political instability on real income per capita growth rate in Jordan. We estimated the following autoregressive distributed lag model (ARDL) ${ }^{16}$ :

15 The data appearing in Figure 1 were normalized by using the E-views software.

16 The model assumes that the growth rate of money supply, the inflation rate, and the growth rate of real investment are the economic determinants of growth rate of real income per capita in Jordan. 
$\Delta L n Y_{t}=\beta_{0}+\sum_{i=1}^{k} \beta_{1 i} \Delta L n M_{t-i}+\sum_{i=0}^{k} \beta_{2 i} \Delta L n P_{t-i}+\sum_{i=0}^{k} \beta_{3 i} \Delta L n I_{t-i}+\sum_{i=0}^{k} \beta_{4 i} \Delta L n Y_{t-i}+\beta_{5} P I_{t}+\eta_{t}$

where $Y_{t}$ denotes the real per capita value, $M_{t}$ stands for money supply, $P_{t}$ is the price level, $I_{t}$ denotes real investment, $P I_{t}$ is a political instability proxy or index, $\eta_{t}$ is the stochastic error where $E\left(\eta_{t}\right)=0, E\left(\eta_{t}{ }^{2}\right)=\sigma_{\eta}{ }^{2}$, and $\beta_{1 i}, \beta_{2 i}, \beta_{3 i}, \beta_{4 i}, \beta_{5}$ are the parameters of the model. We expect $\beta_{1 i}$ and $\beta_{3 i}$ to be positive. However, we predict negative signs for $\beta_{2 i}$ and $\beta_{5}$.

Second, Kalman filter (ML method) is an estimator useful in appraising model parameters as omission of some variables might lead to misspecification, which could result in spurious findings. This technique is the main method used here for assessing the impact of political instability on both economic growth and government expenditure. To apply Kalman filter, we outline a linear Gaussian state space model by the following measurement and state equations:

$$
\begin{gathered}
Y_{t}=A X_{t}+B Z_{t}+\varepsilon_{t}, \quad \varepsilon_{t} \sim \text { iid. }\left(0, \sigma_{\varepsilon \mathrm{t}}^{2}\right) \\
Z_{t}=C Z_{t-1}+u_{t}, \quad u_{t} \sim \text { iid.N }\left(0, \sigma_{u \mathrm{t}}^{2}\right) \\
E\left(\varepsilon_{t}, u_{t}\right)=0
\end{gathered}
$$

The first is a measurement equation linearly relating the observed variable $\left(Y_{t}\right)$ with a vector of exogenous variables $\left(X_{t}\right)$ and a vector of unobserved variable $\left(Z_{t}\right)$. The second is a transition equation describing the dynamics of the unobserved variables. The two error terms, $\varepsilon_{t}$ and $u_{t}$, have zero mean and Gaussian distributions. $A, B$, and $C$ are matrices of parameters. Kalman filter is an optimal recursive data processing algorithm. It uses all the information contained in the model, including errors, uncertainties and unobserved data, to estimate the coefficients of the model. Kalman filter is applied in a state space model. ${ }^{17}$

Next, we estimate the same shape of the ARDL model by employing Kalman filter. In this step, we rewrite eq. [1] to fit the state space model:

$$
\begin{gathered}
\Delta L n Y_{t}=\beta_{1} \Delta L n M_{t}+\beta_{2} \Delta L n P_{t}+\beta_{3} \Delta L n I_{t}+\beta_{4} P I_{t}+U N_{t}+\eta_{t} \\
U N_{t}=\beta_{5} U N_{t-1}+v_{t}
\end{gathered}
$$

where $Y_{t}, M_{t}, P_{t}, I_{t}, P I_{t}$, and $\eta_{t}$ are the same as stated in eq. [1]. $U N_{t}$ represents the unobserved variables, and $v_{t}$ are the stochastic errors where $E\left(\eta_{t}\right)=0$,

17 For more details about the Kalman filter, see Harvey (1989), Hamilton (1994), and Maddala and Kim (1998). 
$E\left(\eta_{t}{ }^{2}\right)=\sigma_{\eta}{ }^{2}, E\left(v_{t}\right)=0, E\left(v_{t}{ }^{2}\right)=\sigma_{v}{ }^{2}$, and $E\left(\eta_{t} v_{t}\right)=0$, and $\beta_{1}, \beta_{2}, \beta_{3}, \beta_{4}, \beta_{5}$ are the coefficients of the model. We also assume that $\beta_{5}$ is smaller than one, which implies that the first-order autoregressive process is stationary. It is useful here to mention that there is no constant in Kalman filter specification because we are modeling detrended data.

\section{Empirical Results}

The first step to extract the results by using ARDL model is to examine whether the data on the level have a unit root or not. This is an important step to avoid creating a spurious regression. Therefore, we conduct three tests: Augmented Dickey-Fuller (ADF), Phillips-Perron (PP) and Kiwathowski-Phillips-SchmidtShin (KPSS) unit root tests on the level with trend and intercept because the data have both. Table 4 presents the results from panel A. The three tests support non-stationary series at the levels of all the four variables. However, the KPSS

Table 4: The unit root tests.

\begin{tabular}{|c|c|c|c|c|}
\hline & & ADF & PP & KPSS \\
\hline \multicolumn{5}{|c|}{ Panel A: Level form, with trend and intercept } \\
\hline $\operatorname{LnM}_{t}$ & $-2.28(0.44)$ & $K=2$ & $-1.07(0.92)$ & $0.17^{\star \star}$ \\
\hline $\operatorname{Ln} P_{t}$ & $-1.61(0.77)$ & $K=1$ & $-0.80(0.96)$ & $0.17^{\star \star}$ \\
\hline$L n I_{t}$ & $-2.02(0.57)$ & $K=0$ & $-2.22(0.47)$ & 0.08 \\
\hline $\operatorname{Ln} Y_{t}$ & $-2.73(0.23)$ & $K=2$ & $-2.16(0.50)$ & 0.07 \\
\hline \multicolumn{5}{|c|}{ Panel B: First difference form, with intercept } \\
\hline $\operatorname{LnM}_{t}$ & $-1.75(0.39)$ & $K=1$ & $-2.65(0.09)^{\star \star \star}$ & 0.30 \\
\hline $\operatorname{Ln} P_{t}$ & $-3.89(0.005)^{\star}$ & $K=0$ & $-3.99(0.004)^{\star}$ & 0.30 \\
\hline$L n I_{t}$ & $-6.18(0.000)^{\star}$ & $K=0$ & $-6.18(0.000)^{\star}$ & 0.13 \\
\hline $\operatorname{Ln} Y_{t}$ & $-2.41(0.14)$ & $K=1$ & $-5.77(0.000)^{\star}$ & 0.12 \\
\hline
\end{tabular}

Notes: the null hypothesis of ADF and PP unit root statistics states that the series is nonstationary against the alternative hypothesis, which is stationary. At the level form, the critical values for the ADF and PP tests are $-4.205,-3.526$, and 3.194 at $1 \%, 5 \%$ and $10 \%$, respectively. The null hypothesis of the KPSS test states that the observed series is stationary versus an alternative of a unit root. The critical values for the KPSS statistics at $1 \%, 5 \%$ and $10 \%$ are $0.216,0.146$ and 0.119 , respectively. The optimal lag length $k$ is determined based on AIC criteria (maximum lag length was 10 ). $p$-Values are reported in parentheses. ${ }^{\star},{ }^{\star \star}$, and ${ }^{\star \star \star}$ represent $1 \%, 5 \%$ and $10 \%$ significance levels, respectively. At the first difference form, the critical values for the ADF and PP tests are $-3.605,-2.936$, and -2.606 at $1 \%, 5 \%$ and $10 \%$, respectively. The critical values for the KPSS statistics at $1 \%, 5 \%$ and $10 \%$ are $0.739,0.463$ and 0.347 , respectively. 
results reveal that real investment and real per capita are stationary at the $1 \%$ level. Also, we perform the three unit root tests on the first difference of the four variables with an intercept. The results reported in panel B of Table 4 show that the three tests assure a stationary series on the first difference for all the four variables. Conversely, the ADF test indicated that both money supply and real per capita have unit roots at the first differences.

Tables 5 and 6 display the estimates from the models with respect to eq. [1] and eq. [2] with eq. [3], respectively. As for determining the optimum lags of the OLS technique (eq. [1]), we use Akaike information criteria to choose the optimum number of lags ${ }^{18}$ combined by running serial correlation. ${ }^{19}$ Given the $F$-statistic critical value of 5.39 at $1 \%$ significance level, the Lagrange Multiplier (LM) test confirms autocorrelation-free residuals. In addition, we test for heteroskedasticity, since the critical $F$-statistic of (2.993 at 1\% significance level), Harvey test cannot reject the null hypothesis of no heteroskedasticity. Further, we check for the stability of the estimated coefficients by employing Ramsey's regression equation specification error test (RESET), and the cumulative sum of the recursive squared residuals (CUSUMQ). In the diagnostic part of Table 5, the Ramsey's RESET test has a chi-squared distribution with a single degree of freedom. Given its critical value of 6.63 at $1 \%$ significance level, we determine that RESET statistic is smaller than the critical value for eq. [1], indicating that the model is correctly specified. Further, the latter test inspects whether the CUSUMQ goes outside the area between the two $5 \%$ critical lines or not. If it goes outside the $5 \%$ critical line, the estimated coefficients are unstable. Figure 2, in Appendix B, shows that the CUSUMQ does not cross the critical line for the five equations ${ }^{20}$ in Table 5 . We thus conclude that the estimated coefficients of the five equations are stable.

The empirical results from our estimation are consistent with economic theory. Jordan's real income per capita growth rate has a statistically significant relationship with money supply growth rate, inflation rate, and real investment growth rate with the correct signs. The growth rates of money supply and real investment have statistically significant and positive relationships with real income per capita growth rate. ${ }^{21}$ Meanwhile, inflation rate has a statistically significant negative relationship with real income per capita growth rate. Likewise, political instability has a statistically significant negative relationship with real income per capita growth rate in Jordan. This statistically significant negative relationship is confirmed with respect to

18 The optimum lag is 1 lag.

19 The results of the test are reported in the diagnostic part of Table 5.

20 Or the five definitions of political instability.

21 With all different forms of political instability. 


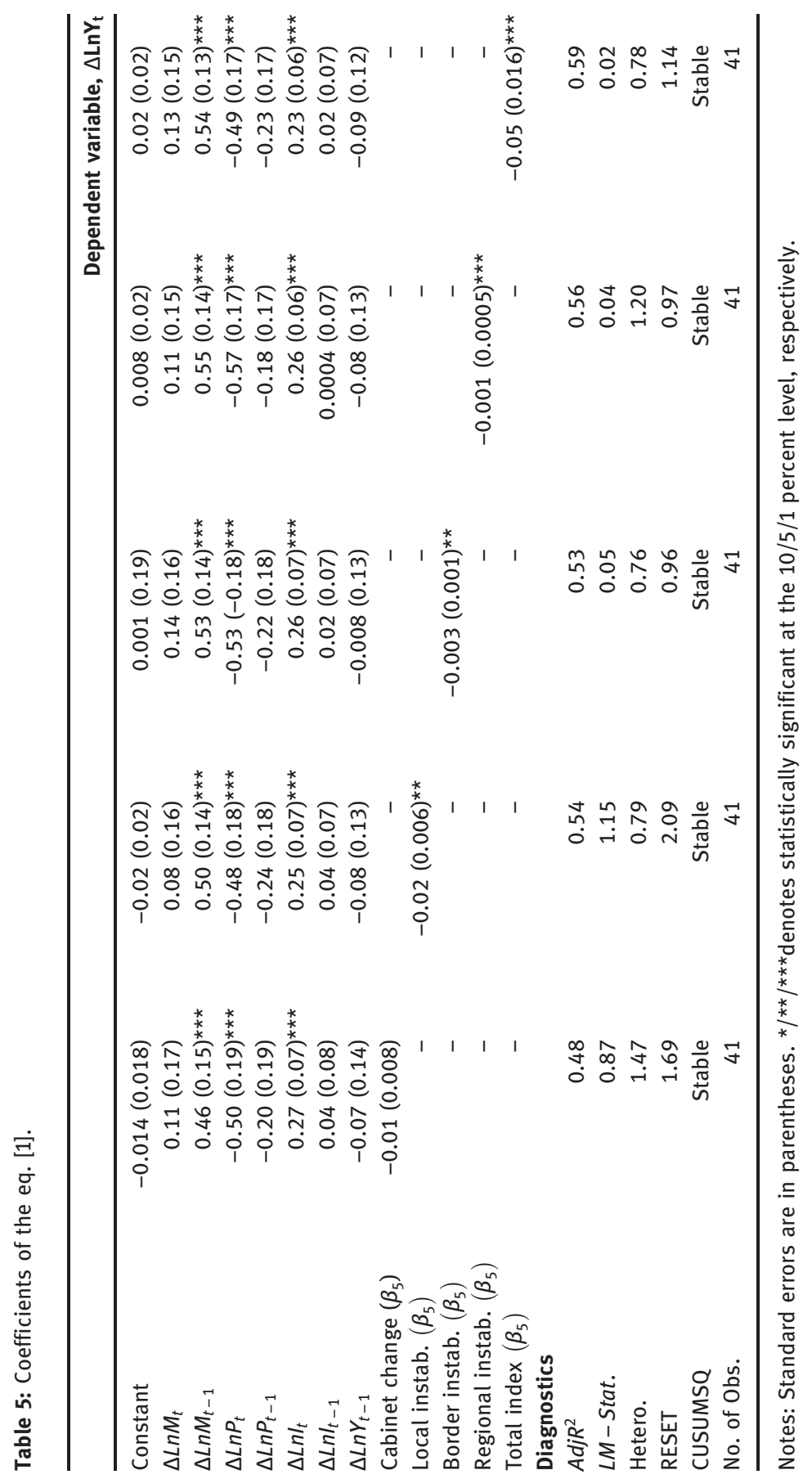




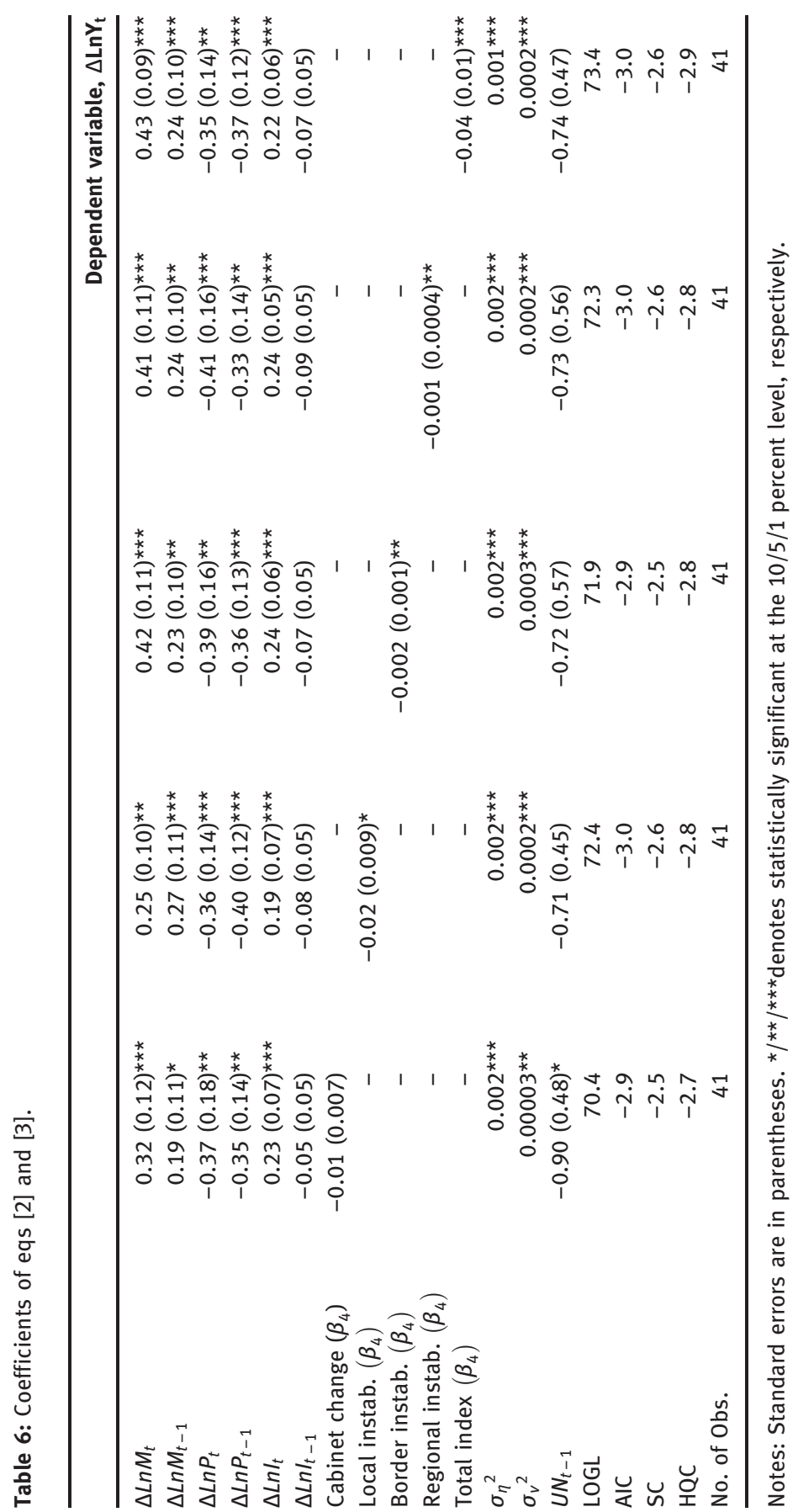


the four political instability types: local instability, border instability, regional and the total or the derived index.

The empirical findings following the application of the Kalman technique are shown in Table 6 . The results are consistent with the results from OLS estimation. Obviously $\sigma_{\eta}{ }^{2}$ and $\sigma_{v}{ }^{2}$ are significantly larger than zero, so we conclude that our model fits the data quite well. However, the differences from zero with regard to unobserved variable coefficients are statistically insignificant for most types of political instability indices except in the cabinet changes equation. ${ }^{22}$ This suggests that the omitted variable is unimportant in explaining real income per capita growth rate in Jordan. On the contrary, political instability proxies are important in explaining the growth rate of real income per capita in Jordan. The results in Table 6 show a statistically significant negative relationship between real income per capita growth rate and the four political instability types. Furthermore, the cabinet changes can be judged to be statistically insignificant since, overall, the quantitative coefficients estimated by the two techniques are very close. Also, the Kalman filter empirical results are consistent with the findings from OLS.

\section{Political Instability and Real Government Expenditures}

In the previous section, we showed that political instability has a negative impact on real income per capita in Jordan. In this section, we expand the analysis by examining the relationship between political instability and real government expenditure by using the Kalman filter technique only. We believe that this extension throws light on a potential channel through which political instability affects economic growth in Jordan. On average, the share of government spending in GDP is $27 \%$. Usually, political instability is accompanied by a greater ambiguity about the stability of the present political regime and/or government; thus its future economic programs and policies. Hence, it is also likely to adversely affect its expenditures. In fact, most previous studies have concentrated on the relationship between political instability and investment (Özler and Rodrik 1992; and Mauro 1995) and inflation rate (Aisen and Veiga 2006; Cukierman, Edwards, and Tabellini 1992). But, none of these studies had

22 Omitting the lags of the exogenous variables makes the unobserved variable statistically significant in most the estimated equations. Adding or neglecting the lagged variables will not affect the estimated parameters and their significance levels. 
focused on the relation between political instability and real government expenditures.

To explore the effect of political instability on real government expenditures in Jordan, we assume that expenditures are determined by the following model:

$$
\begin{gathered}
L n G_{t}=\alpha_{1} \operatorname{Ln}_{t}+\alpha_{2} \operatorname{Ln}_{t}+\alpha_{3} P I_{t}+Z_{t}+\varepsilon_{t} \\
Z_{t}=a_{0}+\alpha_{4} Z_{t-1}+u_{t}
\end{gathered}
$$

where $G_{t}$ denotes real government expenditure, $Q_{t}$ economic growth, $R_{t}$ real government revenues, $P I_{t}$ a political instability proxy, $Z_{t}$ the unobserved variables, $\varepsilon_{t}$ and $u_{t}$ the stochastic errors where $E\left(\varepsilon_{t}\right)=0, E\left(\varepsilon_{t}^{2}\right)=\sigma_{\varepsilon}{ }^{2}$, $E\left(u_{t}\right)=0, E\left(u_{t}^{2}\right)=\sigma_{u}{ }^{2}, E\left(\varepsilon_{t} u_{t}\right)=0$, and $\alpha_{1}, \alpha_{2}, \alpha_{3}, \alpha_{4}$ are the parameters of the model. Also, we assume that $\alpha_{4}$ is smaller than 1 to guarantee that the unobserved variable follows a stationary process. Besides, we assume that the unobserved variable has a drift since the data of the model is not detrended. Hence, the Kalman filter technique is used to estimate eqs [4] and [5].

We estimate eqs [4] and [5] using the ML method; the results are reported in Table 7. Originally, we estimated eqs [4] and [5] with the error term but it seemed the value of the error term of eq. [4], $\left(\varepsilon_{t}\right)$, was nearly equal to zero. This suggested that eq. [4] was deterministic. Therefore, we estimated the system with a single error term $\left(u_{t}\right)$. The results clearly reveal that $\alpha_{3}, \alpha_{4}$, and $\sigma_{u}{ }^{2}$ are significantly different from zero. This confirmed that political instability proxies and the omitted variable were important in clarifying real government expenditures in Jordan. The results shown in Table 7 indicate that, as expected, Jordan's economic growth and government revenues have a statistically significant positive relationship with real government expenditure. All the political instability indices reveal a significant negative influence on real government expenses. This finding confirms that any political instability has indeed hindered Jordanian governments spending.

\section{Conclusions}

Economists have been studying the relationship between political instability and economic growth over the last four decades. Most previous studies have demonstrated that political instability harms economic growth. Further, they showed that the transmission channel consists of disturbances in physical capital, investment, foreign direct investment, and has high inflation rate. By contrast, other studies have found a statistically insignificant link between political instability and the growth rate of real GDP per capita. Most empirical studies on the economics of political instability relied on extracting evidence from panel 


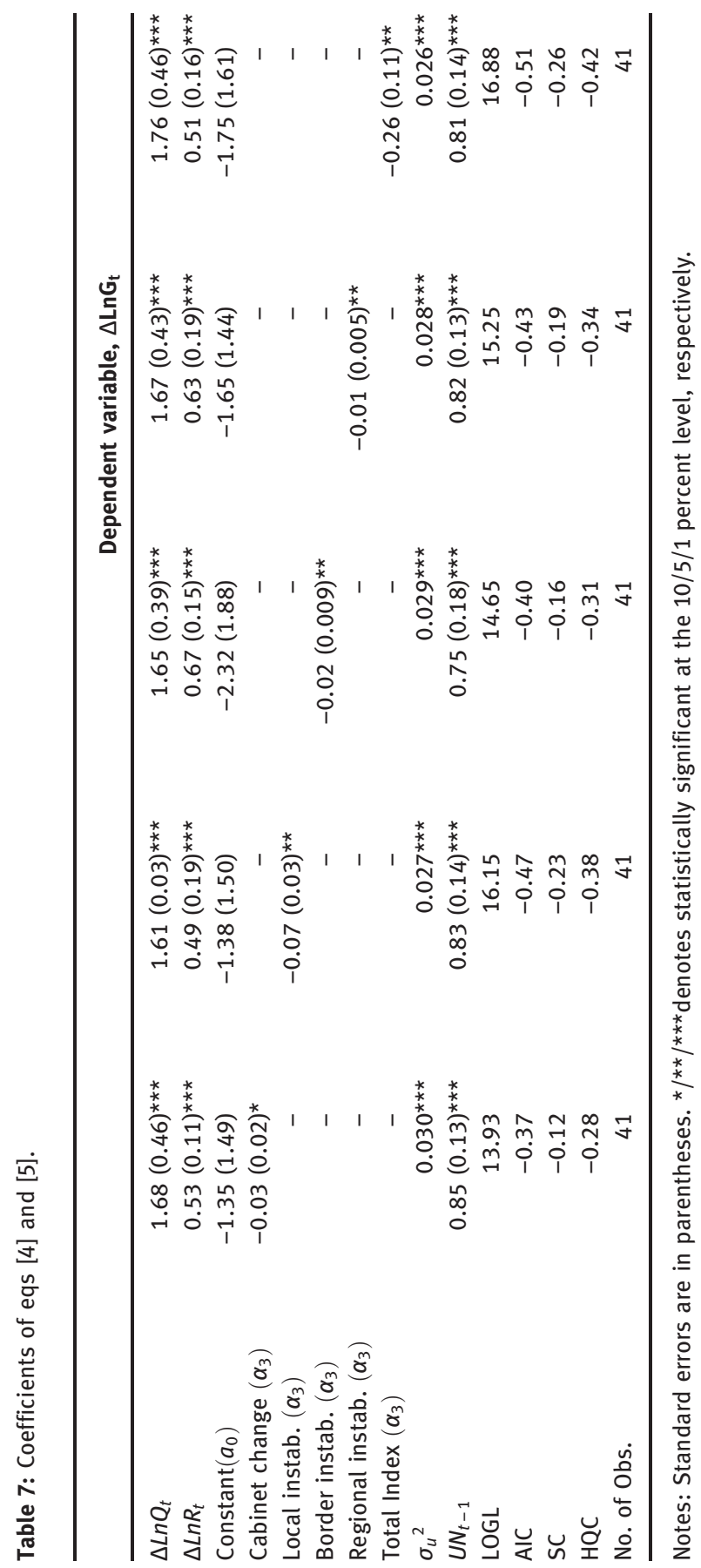


data of many countries. By contrast, the current paper seeks to extract evidence from a single country, Jordan.

We adopted the definition of Gyinmah-Brempong and Traynor (1999) and Burger, Ianchovichina, and Rijkers (2013) for political instability. Based on these definitions and data accessibility, we have examined political instability along four dimensions: cabinet changes in Jordan, local wars and violence, wars and violence in neighboring states, and wars and violence in regional states. Next, we extracted a fifth political instability proxy from the four proxies by using the exploratory factor analysis.

On the empirical side, we have used two techniques, OLS and Kalman filter. The findings from the current paper show that political instability has a negative effect on the growth rate of real income per capita in Jordan. Also, the current paper has concluded that political instability has a negative impact on government expenditures.

Acknowledgments: The author would like to thank the editor and two anonymous referees of Review of Middle East Economics and Finance for their valuable and helpful comments. We are responsible for any errors.

\section{Appendix A: Data}

The present paper uses five forms of political instability which they are: cabinet changes, local instability, border instability, regional instability, and total index. The definition and source of each one is as follows:

Cabinet changes: is the number of each cabinet reshuffles in each year, the source is Jordan's prime minister website; see footnote 2.

Local instability: total major episodes of local political violence. The source is INSCR.

Border instability: total major episodes of political violence of the countries on the border. The source is INSCR.

Regional Instability: total major episodes of political violence of the countries in the region. The source is INSCR.

Total index: this index is calculated by the author from the abovementioned four forms of political instability by using principles factor analysis.

Table 8 presents all these data. 
Table 8: Political instability data in Jordan.

\begin{tabular}{|c|c|c|c|c|c|}
\hline & Cabinet change & Local instability & Boarder instability & Regional instability & Total index \\
\hline 1967 & 4 & 4 & 15 & 30 & 1.66 \\
\hline 1968 & 0 & 4 & 15 & 30 & 1.29 \\
\hline 1969 & 2 & 4 & 15 & 28 & 1.46 \\
\hline 1970 & 5 & 7 & 15 & 31 & 2.04 \\
\hline 1971 & 1 & 0 & 7 & 13 & 0.52 \\
\hline 1972 & 1 & 0 & 7 & 13 & 0.52 \\
\hline 1973 & 1 & 0 & 13 & 17 & 0.83 \\
\hline 1974 & 1 & 0 & 8 & 14 & 0.57 \\
\hline 1975 & 0 & 0 & 8 & 17 & 0.50 \\
\hline 1976 & 3 & 0 & 7 & 15 & 0.72 \\
\hline 1977 & 0 & 0 & 7 & 16 & 0.45 \\
\hline 1978 & 0 & 0 & 9 & 27 & 0.63 \\
\hline 1979 & 1 & 0 & 13 & 31 & 0.94 \\
\hline 1980 & 2 & 0 & 19 & 41 & 1.39 \\
\hline 1981 & 0 & 0 & 20 & 40 & 1.24 \\
\hline 1982 & 0 & 0 & 24 & 48 & 1.49 \\
\hline 1983 & 0 & 0 & 20 & 50 & 1.31 \\
\hline 1984 & 1 & 0 & 20 & 53 & 1.43 \\
\hline 1985 & 1 & 0 & 20 & 53 & 1.43 \\
\hline 1986 & 0 & 0 & 20 & 50 & 1.31 \\
\hline 1987 & 0 & 0 & 20 & 50 & 1.31 \\
\hline 1988 & 0 & 0 & 20 & 48 & 1.30 \\
\hline 1989 & 2 & 0 & 14 & 36 & 1.11 \\
\hline 1990 & 0 & 0 & 19 & 46 & 1.24 \\
\hline 1991 & 2 & 0 & 15 & 50 & 1.26 \\
\hline 1992 & 0 & 0 & 10 & 36 & 0.74 \\
\hline 1993 & 1 & 0 & 10 & 36 & 0.83 \\
\hline 1994 & 0 & 0 & 5 & 25 & 0.42 \\
\hline 1995 & 1 & 0 & 5 & 18 & 0.46 \\
\hline 1996 & 1 & 0 & 6 & 19 & 0.52 \\
\hline 1997 & 1 & 0 & 6 & 19 & 0.52 \\
\hline 1998 & 1 & 0 & 7 & 18 & 0.56 \\
\hline 1999 & 1 & 0 & 3 & 13 & 0.33 \\
\hline 2000 & 1 & 0 & 3 & 9 & 0.30 \\
\hline 2001 & 0 & 0 & 3 & 9 & 0.21 \\
\hline 2002 & 1 & 0 & 3 & 9 & 0.30 \\
\hline 2003 & 2 & 0 & 9 & 14 & 0.71 \\
\hline 2004 & 0 & 0 & 9 & 16 & 0.54 \\
\hline 2005 & 2 & 0 & 9 & 16 & 0.73 \\
\hline 2006 & 0 & 0 & 11 & 20 & 0.67 \\
\hline 2007 & 1 & 0 & 9 & 17 & 0.64 \\
\hline 2008 & 0 & 0 & 8 & 17 & 0.50 \\
\hline 2009 & 1 & 0 & 8 & 15 & 0.58 \\
\hline
\end{tabular}




\section{Appendix B: Plot of Cumulative Sum of the Recursive Squared Residuals}
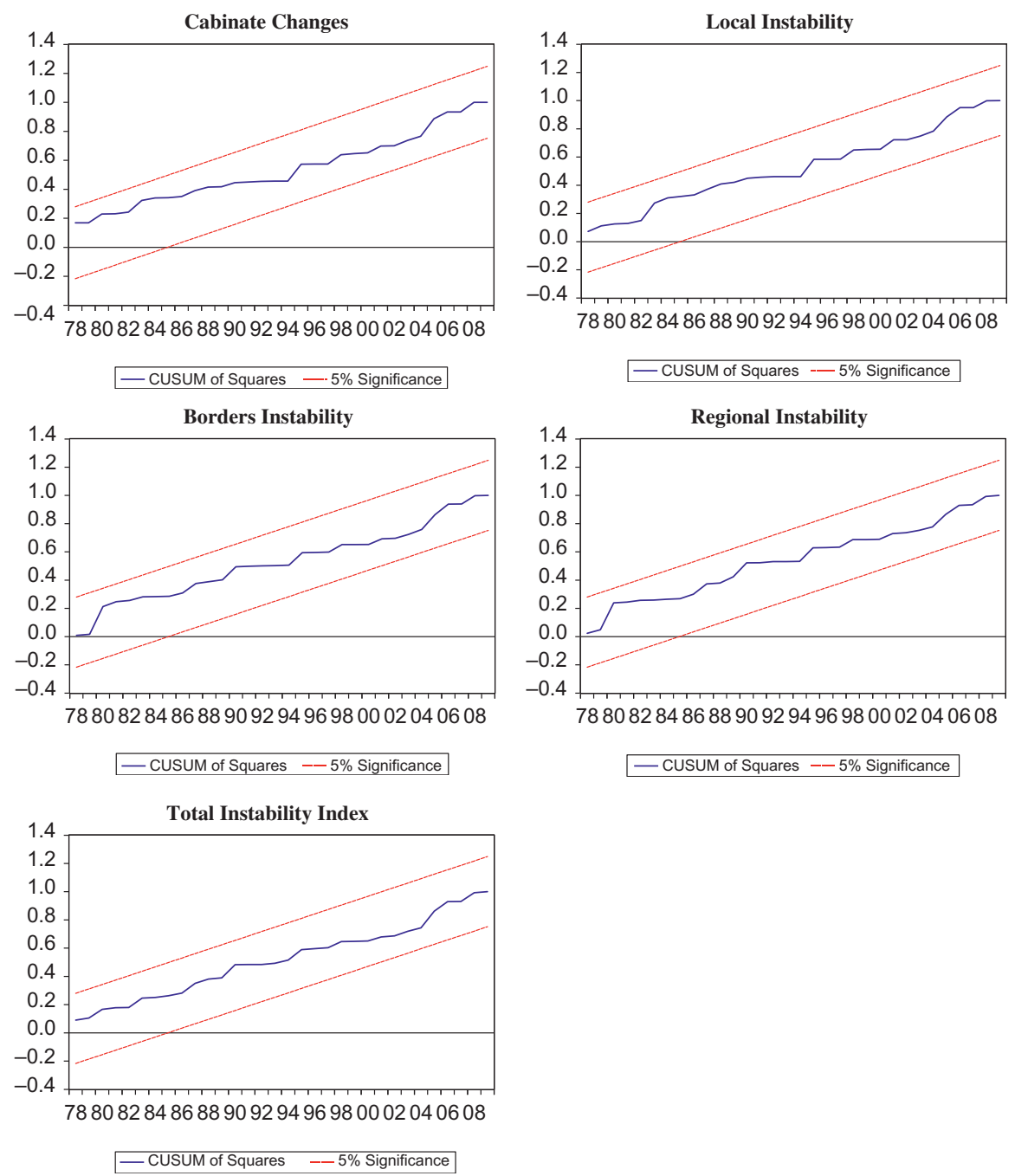

Figure 2: Plot of cumulative sum of the recursive squared residuals (CUSUMQ) for growth rate of real income per capita. 


\section{References}

Aisen, A., and F. J. Veiga. 2006. "Does Political Instability Lead to Higher Inflation? a Panel Data Analysis". Journal of Money, Credit and Banking 38 (5):1379-89.

Aisen, A., and F. J. Veiga. 2013. "How Does Political Instability Affect Economic Growth?” European Journal of Political Economy 29 (March):151-67.

Alesina, A., S. Ozler, N. Roubini, and P. Swagel. 1996. "Political Instability and Economic Growth". Journal of Economic Growth 1 (2):189-211.

Alesina, A., and R. Perotti. 1996. "Income Distribution, Political Instability, and Investment". European Economic Review 40 (6):1203-28.

Alfaro, L., S. Kalemli-Ozcan, and V. Volosovych. 2008. “Why Doesn't Capital Flow From Rich to Poor Countries? An Empirical Investigation." Review of Economics and Statistics 90 (2):347-68.

Barro, R. 1991. “A Cross Country Study of Growth, Saving and Government." In National Saving and Economic Performance, edited by S. Bernheim. Cambridge, MA: NBER.

Burger, M., E. Ianchovichina, and B. Rijkers. 2013. "Political Instability and Greenfield Foreign Direct Investment in the Arab World." The World Bank, Middle East and North Africa Region, Policy Research Working Paper 6716, December.

Busse, M., and C. Hefeker. 2007. "Political Risk, Institutions and Foreign Direct Investment". European Journal of Political Economy 23 (2):397-416.

Campos, N., and J. Nugent. 2002. "Who Is Afraid of Political Instability". Journal of Development Economics 62 (1):157-72.

Campos, N., J. Nugent, and J. A. Robinson. 1999. “Can Political Instability Be Good for Growth? The Case of The Middle East and North Africa." Department of Economics, University of Southern California, January.

Choucair, J. 2006. “Illusive Reform: Jordan’s Stubborn Stability." Carnegie Endowment for International Peace, Carnegie paper, No. 76, December.

Collier, P. 1999. "On the Economic Consequences of Civil War”. Oxford Economic Papers 51 (1):168-83.

Cukierman, A., S. Edwards, and G. Tabellini. 1992. "Seigniorage and Political Instability". American Economic Review 82 (3):537-55.

Daude, C., and E. Stein. 2007. "The Quality of Institutions and Foreign Direct Investment". Economics and Politics 19 (3):317-44.

De Haan, J., and C. Siermann. 1996. "Political Instability, Freedom, and Economic Growth: Some Further Evidence”. Economic Development and Cultural Change 44 (2):339-50.

Gupta, D. 1990. The Economics of Political Violence: The Effect of Political Instability on Economic Growth. New York: Praeger Publishers.

Gyimah-Brempong, K., and T. L. Traynor. 1999. "Political Instability, Investment and Economic Growth in Sub-Saharan Africa”. Journal of African Economies 8 (1):52-86.

Hamilton, J. 1994. Time Series Analysis. Princeton, NJ: Princeton University Press.

Harrigan, J., W. Chengang, and H. El-Said. 2006. "The Economic and Political Determinants of IMF and World Bank Lending in the Middle East and North Africa". World Development 34 (2):247-70.

Harrigan, J., and C. Wang. 2004. "A New Approach to Aid Allocation Among Developing Countries: Is The US More Selfish Than the Rest?" School of Economic Studies Working Paper Series No. 04/11. University of Manchester. 
Hahs-Vaughn, D., and R. Lomax. 2013. An Introduction to Statistical Concepts, 3rd edn. New York: Routledge.

Harvey, A. C. 1989. Forecasting, Structural Time Series Models and the Kalman Filter. Cambridge: Cambridge University Press.

Jong-A-Pin, R. 2009. "On the Measurement of Political Instability and Its Impact on Economic Growth". European Journal of Political Economy 25 (1):15-29.

Kirmanoglu, H. 2003. "Political Freedom and Economic Well-Being: A Causality Analysis." International Conference on Policy Modeling, Istanbul, Turkey.

Maddala, G. S., and I.-M. Kim. 1998. Unit Roots Cointegration, and Structural Change. Cambridge: Cambridge University Press.

Maizels, A., and M. K. Nissanke. 1984. "Motivations for Aid to Developing Countries". World Development 12 (9):879-900.

Mauro, P. 1995. "Corruption and Growth”. Quarterly Journal of Economics 110 (3):681-712.

Olson, M. 1991. “Autocracy, Democracy, and Prosperity." In Richard Zeckhauser, ed., Strategy and Choice.

Ozler, S., and D. Rodrik. 1992. "External Shocks, Politics and Private Investment: Some Theory and Empirical Evidence". Journal of Development Economics 39 (1):141-62.

Ramachandran, S. 2004. Jordan Economic Development in the 1990s and World Bank Assistance. Washington, D.C.: The World Bank.

Rodrik, D. 1989. "Policy Uncertainty and Private Investment in Developing Countries". NBER Working Paper No. 2999.

Rodrik, D. 1995. "Why is There Multilateral Lending”. NBER Working Paper (June) No. W5160.

Schneider, F., and B. S. Frey. 1985. "Economic and Political Determinants of Foreign Direct Investment”. World Development 13 (2):161-75.

Sharp, J. M. 2014. "Jordan: Background and U.S. Relations, Congressional Research Service." January. Available at: http://www.fas.org/sgp/crs/mideast/RL33546.pdf.

Sweidan, 0. 2013. “Exchange Rate Pass-Through Into Import Prices in Jordan”. Global Economy Journal 13 (1):109-28.

United Nation. 2015. "World Economic Situation and Prospects: Chapter One, Global Economic Outlook." Available at: http://www.un.org/en/development/desa/policy/wesp/wesp_ archive/2015wesp_chap1.pdf

Wansbeek, T., and E. Meijer. 2000. Measurement Error and Latent Variables in Econometrics. Amsterdam: North Holland.

Worman, J. G., and D. H. Gray. 2012. "Terrorism in Jordan: Politics and the Real Target Audience". Global Security Studies 3 (3):94-112.

Zablotsky, E. 1996. "Political Stability and Economic Growth.” CEMA Working Papers 109, Universidad del CEMA.

Zeaiter, H., R. El-Khalil, and K. Fakih. 2015. "Economic Development and Sub-Regional Identities" The Journal of Developing Areas 49 (1):157-76.

Zureiqat, H. M. 2005. "Political Instability and Economic Performance: A Panel Data Analysis." http://digitalcommons.macalester.edu/econaward/1. 